\title{
A systematic review of the effectiveness of individual, community and societal level interventions at reducing socioeconomic inequalities in obesity amongst children
}

Frances C Hillier-Brown ${ }^{1,2,3}$, Clare L Bambra ${ }^{1,3^{*}}$, Joanne-Marie Cairns ${ }^{1,3}$, Adetayo Kasim³ ${ }^{3}$ Helen J Moore ${ }^{2,3}$ and Carolyn D Summerbell ${ }^{2,3}$

\begin{abstract}
Background: Tackling childhood obesity is one of the major contemporary public health policy challenges and vital in terms of addressing socioeconomic health inequalities.

We aimed to systematically review studies of the effectiveness of interventions (individual, community and societal) operating via different approaches (targeted or universal) in reducing socio-economic inequalities in obesity-related outcomes amongst children.
\end{abstract}

Methods: Nine electronic databases were searched from start date to October 2012 along with website and grey literature searches. The review examined the best available international evidence from interventions that aimed to prevent obesity, treat obesity, or improve obesity-related behaviours (diet and/or physical activity) amongst children (aged 0-18 years) in any setting and country, so long as they provided relevant information and analysis on both socioeconomic status and obesity-related outcomes. Data extraction and quality appraisal were conducted using established mechanisms and narrative synthesis was conducted.

Results: We located 23 studies that provided the 'best available' (strongest methodologically) international evidence. At the individual level $(n=4)$, there was indicative evidence that screen time reduction and mentoring health promotion interventions could be effective in reducing inequalities in obesity. For the community level interventions ( $n=17)$, evidence was inconclusive - with some studies suggesting that school-based health promotion activities and community-based group-based programmes were effective in reducing obesity - others not. Societal level evaluations were few $(n=1)$. However, there was no evidence to suggest that any of these intervention types increase inequalities and several studies found that interventions could at least prevent the widening of inequalities in obesity. The majority of studies were from America and were of 6-12 year old children.

Conclusions: The review has found only limited evidence although some individual and community based interventions may be effective in reducing socio-economic inequalities in obesity-related outcomes amongst children but further research is required, particularly of more complex, societal level interventions and amongst adolescents.

Keywords: Obesity, Socioeconomic status, Inequalities, Infant, Child, Adolescent, Interventions

\footnotetext{
* Correspondence: clare.bambra@durham.ac.uk

'Department of Geography, Wolfson Research Institute for Health and

Wellbeing, Durham University Queen's Campus, Stockton-on-Tees TS17 6BH,

UK

${ }^{3}$ Wolfson Research Institute for Health and Wellbeing, Durham University

Queen's Campus, Stockton-on-Tees TS17 6BH, UK

Full list of author information is available at the end of the article
}

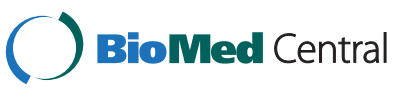

(c) 2014 Hillier-Brown et al.; licensee BioMed Central Ltd. This is an Open Access article distributed under the terms of the Creative Commons Attribution License (http://creativecommons.org/licenses/by/4.0), which permits unrestricted use, distribution, and reproduction in any medium, provided the original work is properly credited. The Creative Commons Public Domain Dedication waiver (http://creativecommons.org/publicdomain/zero/1.0/) applies to the data made available in this article, unless otherwise stated. 


\section{Background}

Persistently high levels of childhood overweight and obesity globally, and the associated health complications, have been well documented [1-3]. In high income countries, evidence from epidemiological studies have continually shown that obesity levels are higher in children of the lowest socioeconomic status [4-10]. Addressing inequalities in obesity therefore has a very high profile on the public health agenda internationally. There is also concern that interventions aiming to prevent and treat obesity are taken up more effectively by the most advantaged groups and therefore widen inequalities in obesity even further [8].

Some effective universal public health interventions may increase inequalities by disproportionately benefitting less disadvantaged groups ('intervention-generated inequalities' or IGIs) [11]. Such IGIs may arise at a number of points in the implementation of an intervention, including intervention efficacy, service provision or access, uptake, and compliance [12]. There is a need to understand which types of interventions are likely to produce IGIs, and which can reduce inequalities. There is a substantial body of theoretical work and guidance on the kinds of interventions which are likely to reduce or increase inequalities [13-15], and Lorenc [16] has conducted a rapid overview of systematic reviews to identify the types of interventions that are more likely to produce IGIs, and which have the potential to reduce inequalities. Lorenc [16] found that media campaigns and workplace smoking bans show some evidence of increasing inequalities (IGIs) between socioeconomic status groups. Data published on IGIs were lacking. However, structural workplace interventions, provision of resources and fiscal interventions such as tobacco pricing showed some evidence of reducing inequalities. Lorenc [16] concluded that their findings are consistent with the idea that 'downstream' preventative interventions are more likely to increase health inequalities than 'upstream' interventions. A subsequent systematic review of universal interventions to reduce smoking confirms these findings; price/tax increases had the most consistent positive equity impact [17].

One would expect that effective targeted (at those most disadvantaged) public health interventions, in contrast, avoid the problem of IGIs. Indeed, this has recently been confirmed by Barr [18] who investigated whether the policy of increasing National Health Service funding to a greater extent in deprived areas of England, compared with more affluent areas, led to a reduction in inequalities in mortality amenable to health care [18]. Using data from a longitudinal ecological study from 2001 to 2011, Barr found that the policy was associated with a reduction in absolute health inequalities. Similar evidence for obesity-related outcomes is scarce. Magnee
[19] reviewed the equity-specific effects of 26 Dutch obesity-related lifestyle interventions (of variable quality and design) but findings were inconsistent. However, a recently published study from Alberta, Canada supports these findings; the quasi-experimental trial found that a 'whole school-based' physical activity promoting intervention targeted at those most disadvantaged, which took an 'upstream' approach, reduced inequalities in physical activity [20].

It is also possible that the way in which a complex intervention is organised and implemented (i.e. context) can impact on its ability to reduce inequalities [21]. For example, a recent systematic review by Durand [22] suggests that interventions which involve shared decisionmaking (and increase participant engagement) may be more beneficial to disadvantaged groups compared with those of higher literacy/socioeconomic status.

Existing systematic reviews only examine the effects of interventions that reduce overall levels of obesity, as opposed to the effects on inequalities in obesity. Therefore, there is a lack of accessible policy ready evidence on what works in terms of interventions to reduce inequalities in childhood obesity. Further, there is increasing recognition amongst policy makers that to effectively tackle complex health problems, such as obesity, and to reduce health inequalities requires integrated policy action across different intervention levels (individual, community, society), as well as across the life course (starting with childhood) $[23,24]$.

\section{How interventions can impact inequalities in childhood obesity}

Interventions can be characterised by their level of action and their approach to tackling inequalities. Whitehead [25] describes four levels of interventions to tackle inequalities: strengthening individuals (person based strategies to improve the health of disadvantaged individuals), strengthening communities (improving the health of disadvantaged communities and local areas by building social cohesion and mutual support - via collective activities), improving living and school environments (reducing exposure to health-damaging material and psychosocial environments across the whole population), and promoting healthy macro policy (improving the macro-economic, cultural and environmental context that influence the standard of living achieved by the whole population). According to Graham and Kelly [14], these interventions are underpinned by one of three different approaches to health inequality: disadvantage (improving the absolute position of the most disadvantaged individuals and groups), gap (reducing the relative gap between the best and worst off groups), or gradient (reducing the entire social gradient). Interventions are thus either targeted (directed at those who are disadvantaged) or 
universal (interventions that influence the entire social gradient).

The aim of this review was to systematically examine the effectiveness of interventions (individual, community and societal) operating via different approaches (targeted or universal) in reducing socio-economic inequalities in obesity-related outcomes amongst children. A companion paper examines interventions for reducing socioeconomic inequalities in obesity amongst adults [26].

\section{Methods}

Our review was carried out following established criteria for the good conduct and reporting of systematic reviews. The full review protocol is published elsewhere [27] and is registered with PROSPERO (CRD42011001740). The full review is available to view at http://www.phr.nihr.ac. uk/funded_projects/obesity.asp [28].

\section{Data sources}

The following electronic databases were searched from their respective start dates up to the $11^{\text {th }}$ October 2012: MEDLINE, EMBASE, CINAHL, PsycINFO, Social Science Citation Index, ASSIA, IBSS, Sociological Abstracts and the NHS Economic Evaluation Database (see Additional file 1 for the full search strategies). We did not exclude papers on the basis of language, country or publication date. The electronic database searches were supplemented with website and grey literature searches.

\section{Types of intervention}

Our review examined interventions at the individual, community and societal (environment and macro policy) level that might reduce inequalities in obesity-related outcomes amongst children aged 0-18 years. Interventions that aimed to prevent obesity, treat obesity, or improve obesity-related behaviours (diet and/or physical activity) were considered relevant, so long as they provided relevant information and analysis on both socioeconomic status and obesity-related outcomes. We defined individual level interventions as those that included individualised/one-to-one health promotion, education, advice, counselling or subsidy and were conducted in a health care or research setting, or in participant's homes. Community level interventions were defined as group-based health promotion, education, advice, counselling or subsidy only interventions, or interventions conducted in a community setting (for example a school, community centre, sports centre and shop). We have classified the group-based educational interventions as community, rather than individual interventions, using 'the intent' of the intervention as an aid to classification [29]. Although we acknowledge that an element of the intent of these types of interventions is to strengthen individuals (increase 'agency') by targeting behaviour change, we believe that the main intent is to target the condition (group setting, peer support, peer pressure, etc) in which behaviour occurs. We do acknowledge that it is a grey area for these types of studies. Societal level studies were split into two sub-groups: Societal-environment level interventions as those that included a change in environment or access to environment; and Societal-policy level interventions as macro-level policies such as taxation, advertising restriction or subsidies. Interventions were also classified in terms of whether they took a gradient approach and included participants of all socio-economic status (SES) ("universal" interventions) or a targeted approach i.e. aimed at low SES participants only ("targeted" interventions). Measures and proxy measures of SES were parental income, parental education, parental occupation, area level or school level disadvantage (for example number of pupils receiving free or reduced school meals). We did not include ethnicity (or faith or culture) as a measure of SES. Interventions that involved drugs or surgery, and laboratory-based studies, were excluded from the review.

Our review considered prevention and treatment interventions that might reduce socioeconomic inequalities in the prevalence of obesity-related outcomes (i.e. effective interventions targeted at low SES children, or universal interventions that work equally or more effectively in low SES children compared with high SES children).

\section{Types of studies}

Our full review [28] included randomised controlled trials (RCTs) and non-randomised controlled trials (classified as experimental studies) that included either a nontreatment control group or standard treatment group, and prospective and retrospective cohort studies, with or without control/standard treatment groups, and prospective repeat cross-sectional studies with or without control/ standard treatment groups (classified as observational studies). Only studies with duration of at least 12 weeks (combination of intervention and follow up) were included. The justification for using a 12 week cut-off was a pragmatic one, in that most existing interventions and initiative, particularly those which are school based, are of a shorter duration, for example over one school term. Given that the aim of our review was to provide useful information for policy makers and commissioners of services, who will be mindful of costs (driven, in part, by duration of the intervention), we did not want to exclude such interventions from our review; the same criteria (and justification) was used in a Cochrane review on interventions to prevent obesity in children [30]. That said, we appreciate that longer term (e.g. one year) changes in obesity-related outcomes would provide a more confident assessment of the effectiveness of such interventions. For the purpose of this article only the best evidence available for each intervention level 
is reported and, therefore, only RCTs and non-randomised controlled trials (experimental studies) were included.

\section{Types of outcome measure}

Studies were included if they reported an obesity-related outcome (e.g. weight and height; body mass index; waist measurement/waist to hip proportion; percentage body fat; skin fold thickness; ponderal index) and if they examined differential effects with regard to socio-economic status, or were targeted specifically at disadvantaged groups or were conducted in deprived areas.

\section{Data extraction and quality appraisal}

The initial screening of titles and abstracts was conducted by one reviewer with a random $10 \%$ of the sample checked by a second reviewer. Data extraction was conducted by one reviewer using established data extraction forms and independently checked by a second reviewer. The methodological quality of the included studies was appraised independently by two reviewers using the Cochrane Public Health Review Group recommended Effective Public Health Practice Project Quality Assessment Tool for Quantitative Studies [31]. This tool includes, amongst other things, an examination of sampling strategy, response and follow-up rates, intervention integrity, statistical analyses and assessment of adjustment for confounders. We used the quality appraisal criteria for descriptive purposes and to highlight variations between studies. Any discrepancies were resolved through discussion between the authors and, if consensus was not reached, with the project lead.

\section{Analysis and synthesis}

Our full review [28] used broad study inclusion criteria and conducted a wide search in order to capture the entire evidence base on the effects of interventions to reduce inequalities in obesity-related outcomes amongst children. This resulted in a very large evidence base that was much larger than anticipated. To make sense of it for policy and practice, this article focuses only on a narrative synthesis of the 'best available' international evidence for each intervention type. Best available evidence was defined in terms of both study design and study quality by each intervention type so that only those studies that provided the highest quality for each intervention type are synthesised in this paper.

\section{Results}

Our database searches identified 70730 records (Figure 1). After title and abstract screening 1668 papers were retrieved. Supplementary searching revealed an additional four studies that met the inclusion criteria for this review. After full paper screening, the 'best available' evidence for each intervention level was obtained from 23 studies (4 individual level, 17 community, 1 societalenvironmental and 1 multi-level interventions).

For the individual level interventions, the 'best available' evidence is provided by moderate quality, experimental studies (randomised and non-randomised controlled trials, randomised and non-randomised cluster trials). For the community level and multi-level interventions, this was provided by strong quality experimental studies. Finally, moderate quality experimental studies were the strongest identified for the societal-environmental level interventions. The descriptions and findings of the 'best available' evidence studies are summarised in Tables 1, 2, 3, 4. Please see (Additional file 2: Tables S1-S4 for effect sizes - where data are available).

\section{Individual ( $\mathrm{n}=\mathbf{4}$ studies)}

Three of the 'best evidence' studies included children of pre-school age (0-5 years), all of the studies included children of primary school age (6-12 years) and one study included children of secondary school age (13-18 years). Three of the studies were conducted in the USA and one in Australia. Study details are summarised in Table 1 with intervention effects sizes reported in Additional file 2: Tables S1-S2 and where data are available. None of the studies in this section were based in a school setting; study settings included healthcare centres, participant's homes, and community sites. The studies included in this section have been grouped by a) those which aimed to prevent further weight gain in children at high risk of obesity, or treat obesity, b) those which aimed to prevent obesity, or improve obesity-related behaviours (diet and/ or physical activity).

\section{Interventions which aimed to prevent further weight gain in} children at high obesity, or treat obesity $(n=3)$

Two of the studies examined tailored weight loss programmes (face to face counselling on healthy diet and physical activity behaviours) delivered via primary care for boys and girls of all SES (universal approach). One was a cluster RCT [32] of 445 children aged 2-6 years conducted in the USA that found that following a one year intervention, there were no changes in BMI overall. However, BMI increased to a lesser extent in the intervention group compared with controls in children with household incomes of $\$ 50,000$ or less (Additional file 2: Table S1). There was no intervention effect amongst children with household incomes greater than $\$ 50,000$ or any differential effects by education status. A RCT [33] of 245 children aged 5-10 years conducted in Australia found that a 12 week intervention led to no significant differences between intervention and control groups for BMI, waist circumference, number overweight or obese at six or twelve months, and SES did 


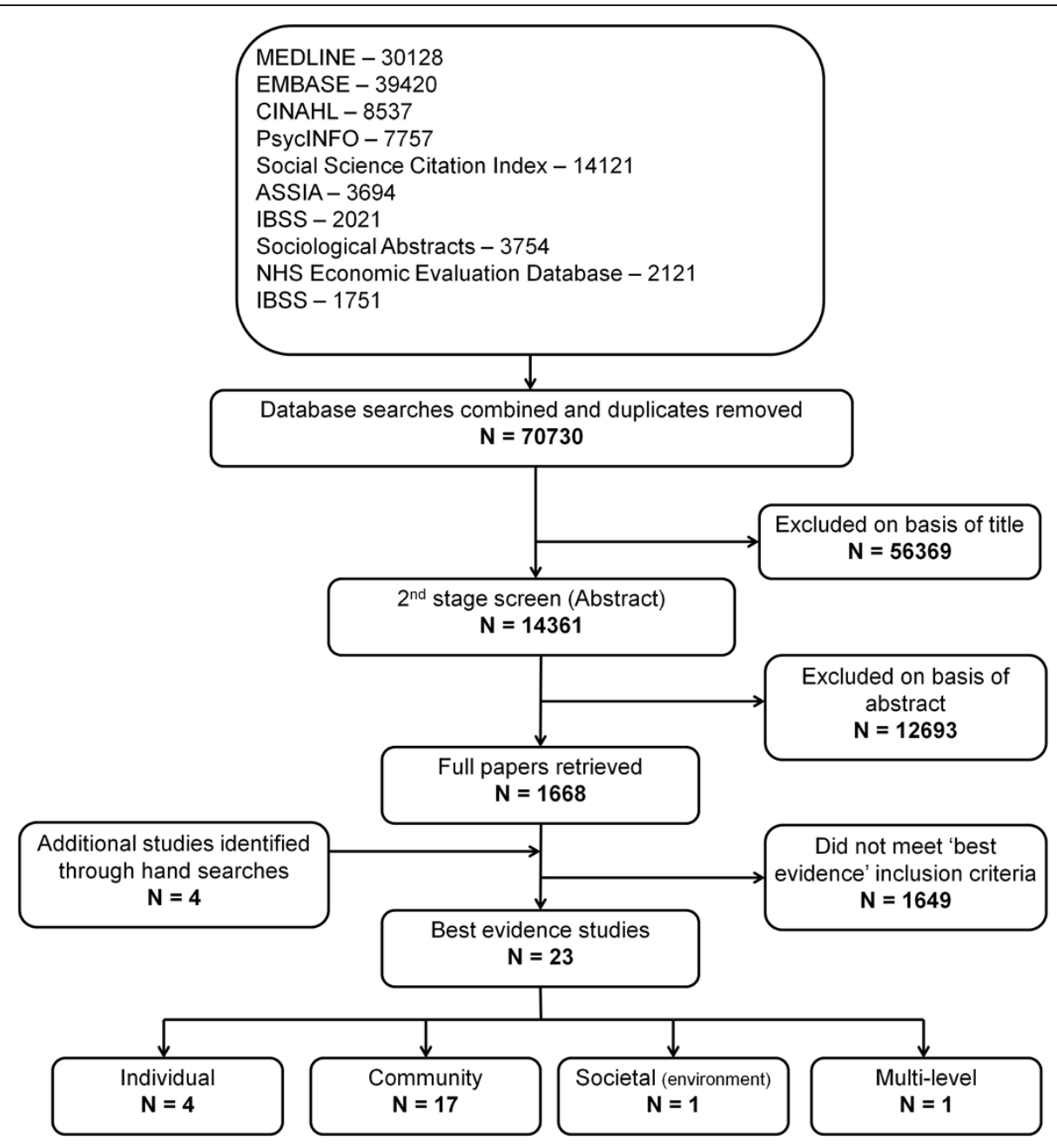

Figure 1 QUOROM statement flow diagram.

not modify the intervention effect (Additional file 2: Table S1).

One RCT conducted in the USA investigated a screen time reduction intervention in 67 overweight children aged 4-7 of all SES (universal approach) [34]. Overall, there were greater reductions in BMI z scores over 24 months in the intervention group compared with controls $(\mathrm{p}<0.05$ for group $x$ time interaction). In the low SES group there was a statistically significant between group difference for change in BMI $\mathrm{z}$ score at 6 months (mean difference between groups $=-0.17 ; \mathrm{p}=0.002), 12$ months $(-0.20 ; \mathrm{p}=0.02)$, 18 months $(-0.17 ; \mathrm{p}=0.04)$ and 24 months $(-0.26 ; \mathrm{p}=0.05)$. There were no statistically significant between group differences in the high SES group.

\section{Interventions which aimed to prevent obesity, or improve} obesity-related behaviours (diet and/or physical activity) $n=1$ The final individual study was a RCT [35] of an eleven week mentor-based health promotion in 179 black adolescents aged 11-16 years from low-income communities in the USA. After two years, there was no difference between intervention and control groups in change of BMI z score from baseline (Additional file 2: Table S2). However, the percentage of overweight and obese participants decreased in the intervention group (IG) compared with the control group (CG) (IG change $=45 \%$ to $39 \%$; $C G=32 \%$ to $43 \%$; $p=0.006)$. Overall, there were no between group differences in changes of percentage body fat, fat mass or fat free mass (Additional file 2: Table S2) but the intervention was effective at reducing percentage fat $(\beta=-1.54 ; p=0.003)$ and fat mass $(\beta=-1.31$; $\mathrm{p}=0.025)$ and increasing fat-free mass $(\beta=1.41 ; \mathrm{p}=0.021)$ in participants who were overweight or obese.

\section{Community ( $\mathrm{n}=17$ studies)}

Half of the 'best evidence' community level studies $(n=7)$ were conducted in the USA with four from South American countries (two from Brazil, and one each from Chile and the Republic of Peru), four from Europe (two from the Netherlands and one each from 
Table 1 Summary details of individual level studies included in the review

\begin{tabular}{|c|c|c|c|c|c|c|c|c|}
\hline \multirow{2}{*}{\multicolumn{2}{|c|}{$\begin{array}{ll}\text { Study } & \begin{array}{l}\text { Design \& quality } \\
\text { Appraisal }\end{array} \\
\text { Individual level interventions }\end{array}$}} & \multirow[t]{2}{*}{ Setting \& participants } & \multirow[t]{2}{*}{ Study aim } & \multirow[t]{2}{*}{ Intervention $^{2}$} & \multirow[t]{2}{*}{ Inequality $^{3}$} & \multicolumn{2}{|c|}{$\begin{array}{l}\text { Summary results }{ }^{4} \uparrow= \\
\text { increase } \downarrow=\text { decrease } \\
\leftrightarrow=\text { no change }\end{array}$} & \multirow[t]{2}{*}{$\begin{array}{l}\text { Impact on inequalities } \\
\text { in obesity }\end{array}$} \\
\hline & & & & & & & & \\
\hline \multirow{2}{*}{$\begin{array}{l}\text { Taveras et al } \\
2011 \text { [32] }\end{array}$} & \multirow{2}{*}{$\begin{array}{l}\text { Cluster RCT; } 1 \text { year } \\
\text { follow-up; Final } \\
\text { sample = } 445 ; \\
\text { Quality = Moderate }\end{array}$} & \multirow{2}{*}{$\begin{array}{l}10 \text { primary care paediatric } \\
\text { centres, USA; } 2-6 \text { years; } 48 \% \\
\text { girls; Obese and high risk } \\
\text { of obese }\end{array}$} & \multirow{2}{*}{$\begin{array}{l}\text { Reduction of BMl in } \\
\text { obese and risk of } \\
\text { obese children }\end{array}$} & \multirow{2}{*}{$\begin{array}{l}\text { Nutrition and physical activity } \\
\text { intervention; Treatment: Weight } \\
\text { management programme (High } \\
\text { Five for Kids) - diet and physical } \\
\text { activity education and counselling, } \\
\text { and behavioural cognitive therapy }\end{array}$} & \multirow{2}{*}{$\begin{array}{l}\text { Universal: results } \\
\text { analysed by household } \\
\text { income }\end{array}$} & BMI (low income) & $\downarrow$ & + \\
\hline & & & & & & BMI (high income) & $\leftrightarrow$ & \\
\hline \multirow{3}{*}{$\begin{array}{l}\text { Wake et al } \\
2009 \text { [33] }\end{array}$} & \multirow{3}{*}{$\begin{array}{l}\text { RCT; } 12 \text { month } \\
\text { follow-up; Final } \\
\text { sample = } 245 ; \\
\text { Quality = Moderate }\end{array}$} & \multirow{3}{*}{$\begin{array}{l}45 \text { family medical practices, } \\
\text { Australia; } 5-10 \text { years; } 61 \% \\
\text { girls; Overweight or mildly } \\
\text { obese }\end{array}$} & \multirow{3}{*}{$\begin{array}{l}\text { Reduce BMI gain in } \\
\text { overweight or mildly } \\
\text { obese children }\end{array}$} & \multirow{3}{*}{$\begin{array}{l}\text { Nutrition and physical activity } \\
\text { intervention; Treatment: Primary } \\
\text { care obesity management } \\
\text { programme (LEAP2) - screening } \\
\text { for overweight/obesity followed } \\
\text { by GP administered counselling } \\
\text { (diet and physical activity) }\end{array}$} & \multirow{3}{*}{$\begin{array}{l}\text { Universal: SES did not } \\
\text { modify any intervention } \\
\text { effect }\end{array}$} & BMI & $\leftrightarrow$ & 0 \\
\hline & & & & & & $\begin{array}{l}\text { Waist } \\
\text { circumference }\end{array}$ & $\leftrightarrow$ & \\
\hline & & & & & & $\begin{array}{l}\text { Prevalence } \\
\text { overweight/ obese }\end{array}$ & $\leftrightarrow$ & \\
\hline \multirow[t]{2}{*}{$\begin{array}{l}\text { Epstein et al } \\
2008 \text { [34] }\end{array}$} & \multirow{2}{*}{$\begin{array}{l}\text { RCT; } 24 \text { month } \\
\text { follow-up; Final } \\
\text { sample }=67 ; \\
\text { Quality }=\text { Moderate }\end{array}$} & \multirow{2}{*}{$\begin{array}{l}\text { Participant's homes, USA; } \\
4-7 \text { years; } \geq 75^{\text {th }} \text { percentile } \\
\text { (at risk of overweight/ } \\
\text { overweight/obese) }\end{array}$} & \multirow{2}{*}{$\begin{array}{l}\text { Reduction of obesity- } \\
\text { related sedentary } \\
\text { behaviours in children } \\
\text { at risk of obesity }\end{array}$} & \multirow{2}{*}{$\begin{array}{l}\text { Physical activity intervention; } \\
\text { Treatment/Prevention: } \\
\text { Intervention to reduce TV } \\
\text { viewing and computer use - } \\
\text { duration of use regulated; } \\
\text { monetary incentives for } \\
\text { reduced use; and newsletters } \\
\text { containing information and } \\
\text { advice }\end{array}$} & \multirow{2}{*}{$\begin{array}{l}\text { Universal: intervention } \\
\text { effect compared between } \\
\text { low SES and high SES } \\
\text { groups }\end{array}$} & $\begin{array}{l}\text { BMl z score } \\
\text { (low SES) }\end{array}$ & $\downarrow$ & + \\
\hline & & & & & & $\begin{array}{l}\text { BMI z score } \\
\text { (high SES) }\end{array}$ & $\leftrightarrow$ & \\
\hline \multirow[t]{10}{*}{$\begin{array}{l}\text { Black et al } \\
2010 \text { [35] }\end{array}$} & \multirow{10}{*}{$\begin{array}{l}\text { RCT; } 24 \text { month } \\
\text { follow-up; Final } \\
\text { sample = 179; } \\
\text { Quality = Moderate }\end{array}$} & \multirow{10}{*}{$\begin{array}{l}\text { Homes and community sites } \\
\text { (e.g. parks and convenience } \\
\text { stores), USA; 11-16 years; } \\
49 \% \text { girls }\end{array}$} & \multirow{10}{*}{$\begin{array}{l}\text { Health promotion } \\
\text { and prevention of } \\
\text { obesity }\end{array}$} & \multirow{10}{*}{$\begin{array}{l}\text { Nutrition and physical activity } \\
\text { intervention; Prevention: } \\
\text { Mentor-based health promotion } \\
\text { and obesity prevention programme } \\
\text { (Challenge!) - Session with mentors } \\
\text { including food preparation, exercise; } \\
\text { goal setting, progress discussions, } \\
\text { and provision of information and } \\
\text { recipes. Rap music video promoting } \\
\text { healthy eating and physical activity }\end{array}$} & \multirow[t]{10}{*}{$\begin{array}{l}\text { Targeted: low-income } \\
\text { communities }\end{array}$} & $\begin{array}{l}\text { Prevalence } \\
\text { overweight/ obese }\end{array}$ & $\downarrow$ & + \\
\hline & & & & & & BMl z score & $\leftrightarrow$ & \\
\hline & & & & & & Ideal weight: & & \\
\hline & & & & & & $\%$ body fat & $\leftrightarrow$ & \\
\hline & & & & & & Fat mass & $\leftrightarrow$ & \\
\hline & & & & & & Fat-free mass & $\leftrightarrow$ & \\
\hline & & & & & & Obese/overweight: & & \\
\hline & & & & & & $\%$ body fat & $\downarrow$ & \\
\hline & & & & & & Fat mass & $\downarrow$ & \\
\hline & & & & & & Fat-free mass & $\uparrow$ & \\
\hline
\end{tabular}

${ }^{1}$ Global Quality appraisal from EPHPP (16); ${ }^{2}$ Prevention or treatment intervention; ${ }^{3}$ Targeted/Universal approach to inequality; ${ }^{4} p<0.05$. This is the relative mean differences between intervention and control at follow-up; ${ }^{5}+$ positive intervention effect so it reduces obesity-related outcomes in low SES groups or reduces the SES gradient in obesity-related outcomes, 0 no intervention effect or no effect on SES gradient in obesity-related outcomes; $S E S=$ Socioeconomic status: $B M I=$ Body mass index 
Finland and France) and one each from Australia and Israel. The majority of studies $(n=13)$ included children of primary school age (6-12 years), three studies included children of preschool age (0-5 years) and one included adolescents (13-18 years). All of the studies included boys and girls (usually an approximately 50/ 50 mix), with the exception of three studies that included girls only. Study details are summarised in Table 2 with intervention effects sizes reported in Additional file 2: Tables S3 and S4 where data are available. The studies included in this section have been grouped, firstly, as school-based interventions or interventions in other settings, and then subdivided (where studies were available) into a) those which aimed to prevent obesity, or improve obesity-related behaviours (diet and/or physical activity) or b) those which aimed to prevent further weight gain in children at high risk of obesity, or treat obesity.

\section{School-based interventions which aimed to prevent obesity, or improve obesity-related behaviours (diet and/or physical activity) $n=12$}

Twelve of the studies examined the effects on obesity related outcomes of school based health promotion interventions. Of these studies, nine investigated nutrition and/or physical activity education combined with exercise sessions; two studies examined education only interventions (diet and/or physical activity); and one study examined a screen time reduction intervention.

Nutrition and/or physical activity education combined with practical sessions $(\mathbf{n}=9)$ Three studies following a targeted approach found some positive results in terms of reducing obesity related indices in low SES children. The first was a non-randomised cluster controlled trial [36] of a six month nutrition and physical activity education intervention in low SES schools in Chile ( $\mathrm{n}=3084$ children aged 11 years on average) that found positive intervention effects for boys in terms of BMI z score but not for BMI, triceps skinfold or waist circumference (Additional file 2: Table S4). No intervention effects were observed amongst girls (Additional file 2: Table S4). The second was a cluster randomised controlled trial [37] of an eight month diet and physical intervention in low income schools in the Netherlands $(\mathrm{n}=2416$ children aged 6-12 years). The intervention consisted of exercise sessions and nutrition, physical activity and healthy lifestyle education. In the younger children (6-9 years) there was no intervention effect for BMI; however, the increase in waist circumference was significantly smaller in the intervention group compared with the control (Additional file 2: Table S4). The prevalence of overweight in the intervention group also increased to a lesser extent compared to the controls. No intervention effects were observed amongst the older age group (Additional file 2: Table S4). The final study was a cluster RCT conducted in 11 kindergartens in low SES communities in Israel $(\mathrm{n}=297$ children aged 4-6 years) [38]. The intervention consisted of nutrition education and daily exercise sessions. Overall, greater decreases in BMI and BMI percentile were observed in the intervention group compared with controls (Additional file 2: Table S4); however, subgroup analysis revealed that this effect only occurred in boys and not girls.

A cluster RCT [39] that followed a universal approach investigated the effects of a cardiovascular disease risk factor reduction intervention delivered over eight weeks in 985 school children aged 8 to 10 years in the USA. Although there was a significant reduction in sum of skin folds from baseline to one year follow-up in the intervention group compared with controls (log of SSF mean change IG $=-0.060 ; \mathrm{CG}=-0.032 ; \mathrm{p}=0.0422$ ), there was no relationship between intervention effects and SES of the children.

The final five studies found no beneficial intervention effects or any impact on inequalities in obesity. A randomised cluster trial [40] of a four-year school based multi-component education and exercise universal intervention to increase physical activity in 732 children aged 11-12 years in France (universal approach). At four year follow-up, intervention children showed a lower increase in age and gender adjusted BMI over time $(\mathrm{p}<0.02)$, although there were no differential effects by SES. A cluster RCT [41] of an eighteen week targeted intervention in 201 low-income, minority pre-school children in the USA. The intervention comprised of physical activity and nutrition education sessions. There were no significant effects on BMI $\mathrm{z}$ score after 18 weeks. A nonrandomised cluster controlled trial [42] investigated a school-based physical activity education and exercise targeted intervention (JUMP-in) among 2064 low SES 6-12 year olds in the Netherlands and found no intervention effects on BMI or waist circumference after 20 months (Additional file 2: Table S4). Another physical activity education and exercise session targeted intervention, delivered after-school, was investigated by a nonrandomised cluster controlled trial [43] in a small sample of largely low-income children aged $10-11$ years $(n=98)$ in the USA. No intervention effects in terms of change in BMI or BMI $\mathrm{z}$ score were observed after five months (Additional file 2: Table S4). A cluster RCT [44] among 294 adolescent girls (mean age $=13.2$ years) in schools in lowincome communities in Australia investigated the effects of a multi-component obesity prevention targeted programme that comprised of nutrition and physical activity education and exercise sessions. After 12 months there were no statistically significant intervention effects in terms of BMI, BMI $\mathrm{z}$ score or body fat change (Additional file 2: Table S4), 
Table 2 Summary details of community level studies included in the review

\begin{tabular}{|c|c|c|c|c|c|c|c|c|}
\hline Study & $\begin{array}{l}\text { Design \& quality } \\
\text { appraisal }^{1}\end{array}$ & Setting \& participants & Study aim & Intervention $^{2}$ & Inequality $^{3}$ & $\begin{array}{l}\text { Summary results }{ }^{4} \uparrow= \\
\text { increase } \downarrow=\text { decrease } \\
\leftrightarrow=\text { no change }\end{array}$ & & $\begin{array}{l}\text { Impact on } \\
\text { inequalities } \\
\text { in obesity }^{5}\end{array}$ \\
\hline \multirow{6}{*}{$\begin{array}{l}\text { Kain et al } \\
2004 \text { [36] }\end{array}$} & \multirow{6}{*}{$\begin{array}{l}\text { Non-randomised } \\
\text { cluster controlled trial; } \\
6 \text { month follow-up; } \\
\text { Final sample = 3086; } \\
\text { Quality = Strong }\end{array}$} & \multirow{6}{*}{$\begin{array}{l}5 \text { Schools, Chile; } 10.6 \\
\text { years; } 47 \% \text { girls }\end{array}$} & \multirow{6}{*}{$\begin{array}{l}\text { Reduction and prevention } \\
\text { of obesity in low SES } \\
\text { children }\end{array}$} & \multirow{6}{*}{$\begin{array}{l}\text { Nutrition and physical activity } \\
\text { intervention; Prevention: } \\
\text { nutrition education (children and } \\
\text { parents), extra time in PE lessons, } \\
\text { encouragement of PA during } \\
\text { daily recess, healthy snacks in } \\
\text { vending machines (voluntary), } \\
\text { incentives for healthy eating and } \\
\text { sports equipment for schools }\end{array}$} & \multirow{6}{*}{$\begin{array}{l}\text { Targeted: Low SES } \\
\text { schools (35\% children } \\
\text { receiving School Lunch } \\
\text { Program) }\end{array}$} & BMl z score (boys) & $\downarrow$ & \multirow[t]{6}{*}{+ (boys) } \\
\hline & & & & & & Triceps skinfold (boys) & $\leftrightarrow$ & \\
\hline & & & & & & $\begin{array}{l}\text { Waist circumference } \\
\text { (boys) }\end{array}$ & $\leftrightarrow$ & \\
\hline & & & & & & BMI z score (girls) & $\leftrightarrow$ & \\
\hline & & & & & & Triceps skinfold (girls) & $\leftrightarrow$ & \\
\hline & & & & & & $\begin{array}{l}\text { Waist circumference } \\
\text { (girls) }\end{array}$ & $\leftrightarrow$ & \\
\hline \multirow{8}{*}{$\begin{array}{l}\text { Jansen et al } \\
2011 \text { [37] }\end{array}$} & \multirow{8}{*}{$\begin{array}{l}\text { Cluster RCT; } 8 \text { month } \\
\text { follow-up; Final } \\
\text { sample = 2416; } \\
\text { Quality = Strong }\end{array}$} & \multirow{8}{*}{$\begin{array}{l}20 \text { Schools, The } \\
\text { Netherlands; } 6-12 \\
\text { years; } 51 \% \text { girls }\end{array}$} & \multirow{8}{*}{$\begin{array}{l}\text { Weight reduction and } \\
\text { prevention of obesity in } \\
\text { low SES children }\end{array}$} & \multirow{8}{*}{$\begin{array}{l}\text { Nutrition and physical } \\
\text { activity intervention; } \\
\text { Prevention: nutrition, } \\
\text { activity living and } \\
\text { healthy lifestyle } \\
\text { education, } 3 \text { PE lessons } \\
\text { per week and voluntary } \\
\text { additional after-school } \\
\text { sport and play activities }\end{array}$} & \multirow{8}{*}{$\begin{array}{l}\text { Targeted: Low } \\
\text { income inner-city, } \\
\text { multi-ethnic schools }\end{array}$} & Children 6-9 years: & & \multirow[t]{8}{*}{ + (6-9 years) } \\
\hline & & & & & & BMl & $\leftrightarrow$ & \\
\hline & & & & & & Waist circumference & $\downarrow$ & \\
\hline & & & & & & Prevalence overweight & $\downarrow$ & \\
\hline & & & & & & Children 9-12 years: & & \\
\hline & & & & & & BMI & $\leftrightarrow$ & \\
\hline & & & & & & Waist circumference & $\leftrightarrow$ & \\
\hline & & & & & & Prevalence overweight & $\leftrightarrow$ & \\
\hline \multirow{4}{*}{$\begin{array}{l}\text { Nemet et al } \\
2011[38]\end{array}$} & \multirow{4}{*}{$\begin{array}{l}\text { Cluster RCT; } 1 \text { year } \\
\text { follow-up; Final } \\
\text { sample = } 297 ; \\
\text { Quality = Strong }\end{array}$} & \multirow{4}{*}{$\begin{array}{l}11 \text { Kindergartens, } \\
\text { Israel; } 4.2-6.5 \text { years; } \\
45 \% \text { girls }\end{array}$} & \multirow[t]{4}{*}{ Prevention of obesity } & \multirow{4}{*}{$\begin{array}{l}\text { Nutrition and physical } \\
\text { activity intervention; } \\
\text { Prevention: Nutrition } \\
\text { education classes and } \\
\text { flyers for parents; exercise } \\
\text { sessions and songs related } \\
\text { to topic of nutrition and } \\
\text { exercise }\end{array}$} & \multirow{4}{*}{$\begin{array}{l}\text { Targeted: kindergarten } \\
\text { in low SES communities }\end{array}$} & BMI (boys) & $\downarrow$ & \multirow[t]{4}{*}{+ (boys) } \\
\hline & & & & & & BMI\% (boys & $\downarrow$ & \\
\hline & & & & & & BMI (girls) & $\leftrightarrow$ & \\
\hline & & & & & & BMI\% (girls) & $\leftrightarrow$ & \\
\hline $\begin{array}{l}\text { Bingham } \\
2002 \text { [39] }\end{array}$ & $\begin{array}{l}\text { Cluster RCT; } 1 \text { year } \\
\text { follow-up; Final } \\
\text { sample = } 985 ; \\
\text { Quality = Strong }\end{array}$ & $\begin{array}{l}12 \text { schools, USA; 8-10 } \\
\text { years; } 51 \% \text { girls }\end{array}$ & CVD risk factor reduction & $\begin{array}{l}\text { Nutrition and physical } \\
\text { activity intervention; } \\
\text { Prevention: CVD risk } \\
\text { factor reduction } \\
\text { intervention - } \\
\text { education (including } \\
\text { nutrition and physical } \\
\text { activity) and physical } \\
\text { activity sessions }\end{array}$ & $\begin{array}{l}\text { Universal: SES was not } \\
\text { found to be a moderator } \\
\text { of the intervention effect }\end{array}$ & Skinfold thickness & $\downarrow$ & 0 \\
\hline \multirow{3}{*}{$\begin{array}{l}\text { Simon et al } \\
2008[40]\end{array}$} & \multirow{3}{*}{$\begin{array}{l}\text { Randomised cluster } \\
\text { trial; } 48 \text { month } \\
\text { follow-up; Final } \\
\text { sample = 732; } \\
\text { Quality = Strong }\end{array}$} & \multirow{3}{*}{$\begin{array}{l}8 \text { schools, Eastern France; } \\
11-12 \text { years; } 50 \% \text { girls }\end{array}$} & \multirow{3}{*}{$\begin{array}{l}\text { Increase physical activity by } \\
\text { changing attitudes, } \\
\text { promoting the social support } \\
\text { of parents and teachers, } \\
\text { making the environment } \\
\text { more supportive of physical } \\
\text { activities }\end{array}$} & \multirow{3}{*}{$\begin{array}{l}\text { Physical activity intervention; } \\
\text { Prevention: physical activity } \\
\text { education and increased } \\
\text { physical activity classes, 'cycling } \\
\text { to school' days and sports } \\
\text { events }\end{array}$} & \multirow{3}{*}{$\begin{array}{l}\text { Universal: no differences } \\
\text { in results by parental } \\
\text { occupation }\end{array}$} & BMI & $\downarrow$ & \multirow[t]{3}{*}{0} \\
\hline & & & & & & Physical activity & $\uparrow$ & \\
\hline & & & & & & TV/video use & $\downarrow$ & \\
\hline
\end{tabular}


Table 2 Summary details of community level studies included in the review (Continued)

\begin{tabular}{|c|c|c|c|c|c|c|c|c|}
\hline$\overline{\text { Study }}$ & $\begin{array}{l}\text { Design \& quality } \\
\text { appraisal }^{1}\end{array}$ & Setting \& participants & Study aim & Intervention $^{2}$ & Inequality $^{3}$ & $\begin{array}{l}\text { Summary results }{ }^{4} \uparrow= \\
\text { increase } \downarrow=\text { decrease } \\
\leftrightarrow=\text { no change }\end{array}$ & & $\begin{array}{l}\text { Impact on } \\
\text { inequalities } \\
\text { in obesity }^{5}\end{array}$ \\
\hline $\begin{array}{l}\text { Bellows } \\
2007 \text { [41] }\end{array}$ & $\begin{array}{l}\text { Cluster RCT; } 18 \text { week } \\
\text { follow-up; Final } \\
\text { sample = 201; } \\
\text { Quality = Strong }\end{array}$ & $\begin{array}{l}4 \text { Head Start centres, } \\
\text { USA; } 3-5 \text { years; } 46 \% \text { girls }\end{array}$ & Prevent obesity & $\begin{array}{l}\text { Nutrition and physical } \\
\text { activity intervention; } \\
\text { Prevention: Food Friends } \\
\text { Get Movin' with Mighty } \\
\text { Moves }^{\mathrm{TM}} \text { intervention - } \\
\text { physical activity sessions } \\
\text { and nutrition education }\end{array}$ & $\begin{array}{l}\text { Targeted: low-income, } \\
\text { ethnic minority } \\
\text { preschoolers }\end{array}$ & BMI z score & $\leftrightarrow$ & 0 \\
\hline \multirow{5}{*}{$\begin{array}{l}\text { de Meij et al } \\
2011 \text { [42] }\end{array}$} & \multirow{5}{*}{$\begin{array}{l}\text { Cluster non- } \\
\text { randomised control } \\
\text { trial; } 20 \text { month } \\
\text { follow-up; Final } \\
\text { sample = 2064; } \\
\text { Quality = Strong }\end{array}$} & \multirow{5}{*}{$\begin{array}{l}19 \text { schools, The } \\
\text { Netherlands; } 6-12 \\
\text { years; } 50 \% \text { girls }\end{array}$} & \multirow{5}{*}{$\begin{array}{l}\text { To increase physical activity } \\
\text { among children living in } \\
\text { socially and economically } \\
\text { deprived areas }\end{array}$} & \multirow{5}{*}{$\begin{array}{l}\text { Physical activity } \\
\text { intervention; Prevention: } \\
\text { physical activity education } \\
\text { and exercise sessions }\end{array}$} & \multirow{5}{*}{$\begin{array}{l}\text { Targeted: majority } \\
\text { of pupils low SES }\end{array}$} & $\mathrm{BMI}$ & $\leftrightarrow$ & \multirow[t]{5}{*}{0} \\
\hline & & & & & & Waist circumference & $\leftrightarrow$ & \\
\hline & & & & & & $\begin{array}{l}\text { Organised sport } \\
\text { participation }\end{array}$ & $\uparrow$ & \\
\hline & & & & & & Physical activity & $\leftrightarrow$ & \\
\hline & & & & & & Fitness & $\leftrightarrow$ & \\
\hline \multirow{3}{*}{$\begin{array}{l}\text { Herrick et al } \\
2012[43]\end{array}$} & \multirow{3}{*}{$\begin{array}{l}\text { Cluster non- } \\
\text { randomised } \\
\text { controlled trial; } 5 \\
\text { month follow-up; } \\
\text { Final sample= 98; } \\
\text { Quality = Strong }\end{array}$} & \multirow{3}{*}{$\begin{array}{l}6 \text { schools, USA; } 10-11 \\
\text { years; } 55 \% \text { girls }\end{array}$} & \multirow{3}{*}{$\begin{array}{l}\text { Increase physical activity } \\
\text { levels }\end{array}$} & \multirow{3}{*}{$\begin{array}{l}\text { Physical activity } \\
\text { intervention; Prevention: } \\
\text { after-school physical } \\
\text { education sessions; } \\
\text { self-management } \\
\text { education }\end{array}$} & \multirow{3}{*}{$\begin{array}{l}\text { Targeted: largely } \\
\text { low-income population }\end{array}$} & $\mathrm{BMl}$ & $\leftrightarrow$ & \multirow[t]{3}{*}{0} \\
\hline & & & & & & BMI z score & $\leftrightarrow$ & \\
\hline & & & & & & MVPA & $\leftrightarrow$ & \\
\hline \multirow{3}{*}{$\begin{array}{l}\text { Lubans et al } \\
2012[44]\end{array}$} & \multirow{3}{*}{$\begin{array}{l}\text { Cluster RCT; } 12 \\
\text { month follow-up; } \\
\text { Final sample = 294; } \\
\text { Quality = Strong }\end{array}$} & \multirow{3}{*}{$\begin{array}{l}12 \text { schools, Australia; } \\
13.2 \text { years; } 100 \% \text { girls }\end{array}$} & \multirow{3}{*}{$\begin{array}{l}\text { Prevention of unhealthy } \\
\text { weight gain in low SES } \\
\text { adolescent girls }\end{array}$} & \multirow{3}{*}{$\begin{array}{l}\text { Nutrition and physical } \\
\text { activity intervention; } \\
\text { Prevention: Nutrition } \\
\text { and Enjoyable Activity } \\
\text { for Teen Girls (NEAT Girls) - } \\
\text { nutrition education; exercise } \\
\text { sessions; self-monitoring; } \\
\text { social support }\end{array}$} & \multirow{3}{*}{$\begin{array}{l}\text { Targeted: schools in } \\
\text { low-income communities }\end{array}$} & $\mathrm{BMI}$ & $\leftrightarrow$ & \multirow[t]{3}{*}{0} \\
\hline & & & & & & BMl z score & $\leftrightarrow$ & \\
\hline & & & & & & Body fat $\%$ & $\leftrightarrow$ & \\
\hline \multirow{2}{*}{$\begin{array}{l}\text { Sichieri et al } \\
2008[45]\end{array}$} & \multirow{2}{*}{$\begin{array}{l}\text { Cluster RCT; } 8 \text { month } \\
\text { follow-up; Final } \\
\text { sample = 927; } \\
\text { Quality = Strong }\end{array}$} & \multirow{2}{*}{$\begin{array}{l}22 \text { schools, Brazil; 10-11 } \\
\text { years; } 53 \% \text { girls }\end{array}$} & \multirow{2}{*}{$\begin{array}{l}\text { Prevention of excess } \\
\text { weight gain }\end{array}$} & \multirow[b]{2}{*}{$\begin{array}{l}\text { Nutrition intervention; } \\
\text { Prevention: educational } \\
\text { intervention to reduce } \\
\text { consumption of sugar- } \\
\text { sweetened beverages } \\
\text { and encourage water } \\
\text { consumption }\end{array}$} & \multirow{2}{*}{$\begin{array}{l}\text { Targeted: children from } \\
\text { low SES families }\end{array}$} & BMI (overall) & $\leftrightarrow$ & \multirow{2}{*}{$\begin{array}{l}+ \text { (overweight } \\
\text { girls) }\end{array}$} \\
\hline & & & & & & BMI (overweight girls) & $\downarrow$ & \\
\hline \multirow{2}{*}{$\begin{array}{l}\text { Walter et al } \\
1985 \text { [46] }\end{array}$} & \multirow{2}{*}{$\begin{array}{l}\text { Cluster RCT; } 1 \text { year } \\
\text { follow-up; Final } \\
\text { sample = 1115; } \\
\text { Quality = Strong }\end{array}$} & \multirow{2}{*}{$\begin{array}{l}22 \text { Schools, USA; } 9 \text { years; } \\
49 \% \text { girls }\end{array}$} & \multirow{2}{*}{$\begin{array}{l}\text { Prevention of chronic } \\
\text { disease risk factors } \\
\text { (including obesity) }\end{array}$} & \multirow{2}{*}{$\begin{array}{l}\text { Nutrition and physical } \\
\text { activity intervention; } \\
\text { Prevention: "Know Your } \\
\text { Body" curriculum focusing } \\
\text { on nutrition physical fitness } \\
\text { and smoking prevention }\end{array}$} & \multirow{2}{*}{$\begin{array}{l}\text { Targeted: Children from } \\
\text { low income families }\end{array}$} & Ponderosity index & $\leftrightarrow$ & \multirow[t]{2}{*}{0} \\
\hline & & & & & & $\begin{array}{l}\text { Triceps skinfold } \\
\text { thickness }\end{array}$ & $\leftrightarrow$ & \\
\hline
\end{tabular}


Table 2 Summary details of community level studies included in the review (Continued)

\begin{tabular}{|c|c|c|c|c|c|c|c|c|}
\hline Study & $\begin{array}{l}\text { Design \& quality } \\
\text { appraisal }^{7}\end{array}$ & Setting \& participants & Study aim & Intervention $^{2}$ & Inequality $^{3}$ & $\begin{array}{l}\text { Summary results }{ }^{4} \uparrow= \\
\text { increase } \downarrow=\text { decrease } \\
\leftrightarrow=\text { no change }\end{array}$ & & $\begin{array}{l}\text { Impact on } \\
\text { inequalities } \\
\text { in obesity }\end{array}$ \\
\hline \multirow{4}{*}{$\begin{array}{l}\text { Robinson } \\
1999[47]\end{array}$} & \multirow{4}{*}{$\begin{array}{l}\text { Randomised cluster } \\
\text { trial; } 6 \text { month } \\
\text { follow-up; Final } \\
\text { sample = 192; } \\
\text { Quality = Strong }\end{array}$} & \multirow{4}{*}{$\begin{array}{l}2 \text { schools, USA; 8-9 years; } \\
45 \% \text { girls }\end{array}$} & \multirow{4}{*}{$\begin{array}{l}\text { Prevent the onset of } \\
\text { obesity }\end{array}$} & \multirow{4}{*}{$\begin{array}{l}\text { Physical activity } \\
\text { intervention; Prevention: } \\
\text { education course to reduce } \\
\text { TV and video game use } \\
\text { including a } 10 \text { day TV turn } \\
\text { off. Home TV usage monitor. } \\
\text { Parental education materials }\end{array}$} & \multirow{4}{*}{$\begin{array}{l}\text { Universal: no differences } \\
\text { in results by parental } \\
\text { education }\end{array}$} & $\mathrm{BMI}$ & $\downarrow$ & \multirow[t]{4}{*}{0} \\
\hline & & & & & & $\begin{array}{l}\text { Triceps skin fold } \\
\text { thickness }\end{array}$ & $\downarrow$ & \\
\hline & & & & & & Waist circumference & $\downarrow$ & \\
\hline & & & & & & Waist-hip ratio & $\downarrow$ & \\
\hline \multirow{3}{*}{$\begin{array}{l}\text { Kalavainen } \\
\text { et al } 2007 \text { [48] }\end{array}$} & \multirow{3}{*}{$\begin{array}{l}\text { RCT; } 12 \text { month } \\
\text { follow-up; Final } \\
\text { sample = 69; } \\
\text { Quality = Strong }\end{array}$} & \multirow{3}{*}{$\begin{array}{l}1 \text { Health care centre, } \\
\text { Finland; } 7-9 \text { years; } 60 \% \\
\text { girls; Obese }\end{array}$} & \multirow[t]{3}{*}{ Treatment of obesity } & \multirow{3}{*}{$\begin{array}{l}\text { Nutrition and physical } \\
\text { activity intervention; } \\
\text { Treatment: Family-based } \\
\text { group treatment programme - } \\
\text { diet and physical activity } \\
\text { education and behavioural } \\
\text { therapy }\end{array}$} & \multirow{3}{*}{$\begin{array}{l}\text { Universal: No association } \\
\text { between social class and } \\
\text { obesity-related outcomes }\end{array}$} & Weight for height & $\downarrow$ & \multirow[t]{3}{*}{0} \\
\hline & & & & & & BMI & $\downarrow$ & \\
\hline & & & & & & BMI SDS & $\leftrightarrow$ & \\
\hline $\begin{array}{l}\text { Alves et al } \\
2008 \text { [49] }\end{array}$ & $\begin{array}{l}\text { RCT; } 6 \text { month } \\
\text { follow-up; Final } \\
\text { sample = 68; } \\
\text { Quality = Strong }\end{array}$ & $\begin{array}{l}\text { Community setting } \\
\text { (exact setting unclear), } \\
\text { Brazil; 5-10 years; 49\% } \\
\text { girls; Overweight }\end{array}$ & $\begin{array}{l}\text { Increase physical activity } \\
\text { in overweight children to } \\
\text { reduce BMl }\end{array}$ & $\begin{array}{l}\text { Physical activity intervention; } \\
\text { Treatment: Physical activity } \\
\text { sessions } 3 \text { times per week }\end{array}$ & $\begin{array}{l}\text { Targeted: Children from } \\
\text { a disadvantaged area }\end{array}$ & BMl & $\downarrow$ & + \\
\hline \multirow{2}{*}{$\begin{array}{l}\text { Robinson et } \\
\text { al } 2003 \text { [50] }\end{array}$} & \multirow{2}{*}{$\begin{array}{l}\text { RCT (pilot); } 12 \text { week } \\
\text { follow-up; Final } \\
\text { sample = } 60 ; \\
\text { Quality = Strong }\end{array}$} & \multirow{2}{*}{$\begin{array}{l}\text { Community centres and } \\
\text { homes, USA; 8-10 years; } \\
100 \% \text { girls; At risk of } \\
\text { obesity }\end{array}$} & \multirow{2}{*}{$\begin{array}{l}\text { Prevent further weight } \\
\text { gain in low SES African } \\
\text { American girls }\end{array}$} & \multirow{2}{*}{$\begin{array}{l}\text { Physical activity intervention; } \\
\text { Treatment: Dance classes } \\
\text { and TV viewing reduction } \\
\text { intervention (GEMS) } \\
\text { targeting African } \\
\text { American girls at risk } \\
\text { of obesity }\end{array}$} & \multirow{2}{*}{$\begin{array}{l}\text { Targeted: Recruited from } \\
\text { low income neighbourhoods }\end{array}$} & BMl & $\leftrightarrow$ & \multirow[t]{2}{*}{0} \\
\hline & & & & & & Waist circumference & $\leftrightarrow$ & \\
\hline \multirow{2}{*}{$\begin{array}{l}\text { Willet } 1995 \\
\text { [51] }\end{array}$} & \multirow{2}{*}{$\begin{array}{l}\text { Non-randomised } \\
\text { controlled trial; } 1 \\
\text { year follow-up; Final } \\
\text { sample = 40; } \\
\text { Quality = Strong }\end{array}$} & \multirow{2}{*}{$\begin{array}{l}1 \text { community setting } \\
\text { (exact setting unclear), } \\
\text { USA; } 7-12 \text { years; } 100 \% \\
\text { girls }\end{array}$} & \multirow{2}{*}{$\begin{array}{l}\text { Prevention of obesity in } \\
\text { low income African } \\
\text { American girls }\end{array}$} & \multirow[b]{2}{*}{$\begin{array}{l}\text { Nutrition and physical activity } \\
\text { intervention; Prevention: } \\
\text { Mother and daughter } \\
\text { culturally specific obesity } \\
\text { prevention programme } \\
\text { (based on the Know Your } \\
\text { Body health education } \\
\text { curriculum) }\end{array}$} & \multirow{2}{*}{$\begin{array}{l}\text { Targeted: low SES, } \\
\text { African American girls }\end{array}$} & BMl & $\leftrightarrow$ & 0 \\
\hline & & & & & & $\%$ overweight & $\leftrightarrow$ & \\
\hline \multirow{2}{*}{$\begin{array}{l}\text { Hamad et al } \\
2011[52]\end{array}$} & \multirow{2}{*}{$\begin{array}{l}\text { RCT; } 1 \text { year follow-up; } \\
\text { Final sample = 1501; } \\
\text { Quality = Strong }\end{array}$} & \multirow{2}{*}{$\begin{array}{l}\text { Microcredit institution, } \\
\text { Republic of Peru; } \\
<5 \text { years }\end{array}$} & \multirow{2}{*}{$\begin{array}{l}\text { To improve the general } \\
\text { health of disadvantaged } \\
\text { children }\end{array}$} & \multirow{2}{*}{$\begin{array}{l}\text { Nutrition and physical } \\
\text { activity intervention; } \\
\text { Prevention: Microcredit } \\
\text { loan with the addition } \\
\text { of health education } \\
\text { sessions to parents }\end{array}$} & \multirow{2}{*}{$\begin{array}{l}\text { Targeted: children of } \\
\text { families receiving } \\
\text { microcredit }\end{array}$} & BMI & $\leftrightarrow$ & \multirow[t]{2}{*}{0} \\
\hline & & & & & & $\%$ overweight & $\leftrightarrow$ & \\
\hline
\end{tabular}

Global Quality appraisal from EPHPP (16); ${ }^{2}$ Prevention or treatment intervention; ${ }^{3}$ Targeted/Universal approach to inequality; ${ }^{4} \mathrm{p}<0.05$. This is the relative mean differences between intervention and control at follow-
$5+$ positive intervention effect so it reduces obesity-related outcomes in low SES groups or reduces the SES gradient in obesity-related outcomes, 0 no intervention effect or no effect on SES gradient in obesity-related outcomes; SES = Socioeconomic status; BMI = Body mass index; MVPA = Moderate to vigorous intensity physical activity . 
Table 3 Summary details of the societal level study included in the review

\begin{tabular}{|c|c|c|c|c|c|c|c|c|}
\hline Study & $\begin{array}{l}\text { Design \& quality } \\
\text { appraisal }^{+}\end{array}$ & Setting \& participants & Study aim & Intervention ${ }^{2}$ & Inequality $^{3}$ & $\begin{array}{l}\text { Summary results }{ }^{4} \uparrow= \\
\text { increase } \downarrow=\text { decrease } \\
\leftrightarrow=\text { no change }\end{array}$ & & $\begin{array}{l}\text { Impact on } \\
\text { inequalities } \\
\text { in obesity }\end{array}$ \\
\hline \multirow{8}{*}{$\begin{array}{l}\text { Bürgi et al } 2012 \text { [53] and } \\
\text { Puder et al } 2011 \text { [54] }\end{array}$} & \multirow{8}{*}{$\begin{array}{l}\text { Cluster RCT; } 9.5 \\
\text { month follow-up; } \\
\text { Final sample = 625; } \\
\text { Quality = Strong }\end{array}$} & \multirow{8}{*}{$\begin{array}{l}40 \text { schools, Switzerland; } \\
5.2 \text { years; } 50 \% \text { girls }\end{array}$} & \multirow{8}{*}{$\begin{array}{l}\text { Reduce obesity and } \\
\text { improve fitness levels } \\
\text { in children from socially } \\
\text { disadvantaged backgrounds }\end{array}$} & \multirow{8}{*}{$\begin{array}{l}\text { Nutrition and physical activity } \\
\text { intervention; Prevention: Built } \\
\text { environment adapted to } \\
\text { promote physical activity } \\
\text { (fixed and mobile equipment) } \\
\text { plus exercise sessions; nutrition } \\
\text { education; information and } \\
\text { discussion evenings for parents }\end{array}$} & \multirow{8}{*}{$\begin{array}{l}\text { Universal: trend for } \\
\text { greater intervention } \\
\text { effectiveness in higher } \\
\text { SES children but not } \\
\text { statistically significant }\end{array}$} & BMI & $\leftrightarrow$ & \multirow[t]{8}{*}{0} \\
\hline & & & & & & Body fat\% ( $\%$ SES) & $\downarrow$ & \\
\hline & & & & & & Body fat ( $\downarrow S E S)$ & $\leftrightarrow$ & \\
\hline & & & & & & Skinfold thickness & $\downarrow$ & \\
\hline & & & & & & Waist circumference & $\downarrow$ & \\
\hline & & & & & & Overweight prevalence & $\leftrightarrow$ & \\
\hline & & & & & & Fitness ( $\uparrow$ SES) & $\uparrow$ & \\
\hline & & & & & & Fitness ( $\downarrow S E S)$ & $\leftrightarrow$ & \\
\hline
\end{tabular}

${ }^{1}$ Global Quality appraisal from EPHPP (16); ${ }^{2}$ Prevention or treatment intervention; ${ }^{3}$ Targeted/Universal approach to inequality; ${ }^{4} \mathrm{p}<0.05$. This is the relative mean differences between intervention and control at follow-up; ${ }^{5}+$ positive intervention effect so it reduces obesity-related outcomes in low SES groups or reduces the SES gradient in obesity-related outcomes, 0 no intervention effect or no effect on SES gradient in obesity-related outcomes; SES = Socioeconomic status; $B M I=$ Body mass index 
Table 4 Summary details of the multi-level study included in the review

\begin{tabular}{|c|c|c|c|c|c|c|c|c|}
\hline Study & Design \& quality appraisal ${ }^{1}$ & Setting \& participants & Study aim & Intervention ${ }^{2}$ & Inequality $^{3}$ & $\begin{array}{l}\text { Summary results }{ }^{4} \uparrow= \\
\text { increase } \downarrow=\text { decrease } \\
\leftrightarrow=\text { no change }\end{array}$ & & $\begin{array}{l}\text { Impact on } \\
\text { inequalitie } \\
\text { in obesity }\end{array}$ \\
\hline \multirow{3}{*}{$\begin{array}{l}\text { Sanigorski et al } \\
2008 \text { [55] }\end{array}$} & \multirow{3}{*}{$\begin{array}{l}\text { Quasi-experimental including } \\
\text { cluster RCT; } 3 \text { year follow-up; } \\
\text { Final sample = 1807; } \\
\text { Quality = Strong }\end{array}$} & \multirow{3}{*}{$\begin{array}{l}\text { Community (environmental } \\
\text { and policy), Australia; 4-12 } \\
\text { years; } \approx 50 \% \text { girls }\end{array}$} & \multirow{3}{*}{$\begin{array}{l}\text { Reduce prevalence } \\
\text { of childhood } \\
\text { obesity }\end{array}$} & \multirow{3}{*}{$\begin{array}{l}\text { Nutrition and physical } \\
\text { activity intervention; } \\
\text { Prevention: Community } \\
\text { capacity-building programme. } \\
\text { Intervention included all } \\
\text { manner of things. Targeted } \\
\text { a variety of diet, physical } \\
\text { activity and sedentary } \\
\text { behaviours }\end{array}$} & \multirow{3}{*}{$\begin{array}{l}\text { Universal: No association } \\
\text { between intervention effect } \\
\text { and SES; SES associated with } \\
\text { weight gain in control group }\end{array}$} & Waist circumference & $\downarrow$ & \multirow[t]{3}{*}{+} \\
\hline & & & & & & $\mathrm{BMI}$ & $\leftrightarrow$ & \\
\hline & & & & & & BMI z-score & $\downarrow$ & \\
\hline
\end{tabular}

${ }^{1}$ Global Quality appraisal from EPHPP (16); ${ }^{2}$ Prevention or treatment intervention; ${ }^{3}$ Targeted/Universal approach to inequality; ${ }^{4} \mathrm{p}<0.05$.This is the relative mean differences between intervention and control at follow-up; ${ }^{5}+$ positive intervention effect so it reduces obesity-related outcomes in low SES groups or reduces the SES gradient in obesity-related outcomes, 0 no intervention effect or no effect on SES gradient in obesity-related outcomes; SES = Socioeconomic status; $B M I=$ Body mass index. 
although, there was a trend towards more beneficial changes in the intervention group for all of the outcomes.

Nutrition and/or physical activity education only $(\mathbf{n}=\mathbf{2})$ Two cluster RCTs examined education only interventions that were targeted at children aged 9-11 from low SES schools in the USA and Brazil. The Brazilian study was a cluster RCT [45] of an eight-month intervention to reduce sugar-sweetened beverage intake in schools that encouraged water consumption via competitions, promotions and provision of water bottles. It found no significant differences for all children (Additional file 2: Table S4), however, for girls - not boys - who were overweight at baseline there was a significant reduction of BMI in the intervention group (regression coefficient $=-0.01 ; \mathrm{p}=0.009)$. However, the USA cluster RCT showed no intervention effect of a diet and physical activity education only intervention after one year [46] (Additional file 2: Table S4).

Screen time reduction only $(\mathbf{n}=\mathbf{1})$ A cluster randomised trial [47] investigated a screen time reduction universal intervention and showed beneficial effects in children aged 8 and 9 years after six months that were not associated with child SES. Post intervention, children in the intervention group had statistically significant relative reductions in: BMI (adjusted difference $=-0.45 \mathrm{~kg} / \mathrm{m}^{2} 95 \%$ CI -0.73 to $-0.17, \mathrm{p}=0.002$ ) as well as triceps skin fold thickness (adjusted difference $=-1.47 \mathrm{~mm}, 95 \%$ CI -2.41 to $-0.54, \mathrm{p}=0.002$ ); waist circumference (adjusted difference $=-2.30 \mathrm{~cm}, 95 \% \mathrm{CI}-3.27$ to $-1.33, \mathrm{p}<0.001)$; and waist-hip ratio (adjusted difference $=-0.02,95 \%$ CI -0.03 to $-0.01, \mathrm{p}<0.001)$. The results did not differ by SES.

Interventions in non-school settings which aimed to prevent further weight gain in children at high obesity, or treat obesity $(\mathbf{n}=\mathbf{3})$ Three of the 'best evidence' community level interventions evaluated group-based weight loss programmes. One was a RCT [48] of a six month family-based education and behavioural therapy universal programme compared with a standard treatment programme in 69 obese children aged 7-9 years in Finland of all SES. Beneficial intervention effects were observed: intervention children lost more weight for height than those receiving the routine treatment after six (IG 6.8\% reduction; CG $1.8 \%$ reduction; $\mathrm{p}=0.001$ ) and twelve months (IG mean $3.4 \%$ reduction; CG mean $1.8 \%$ increase, $\mathrm{p}=0.008$ ) and there was a greater decrease in BMI in intervention children compared with routine treatment controls (IG change $=-0.8, \mathrm{CG}=0.0$, $\mathrm{p}=0.003)$. However, there was no association between SES and outcomes (Additional file 2: Table S3).

The other two studies investigated exercise based weight loss programmes and found promising short term (<six months) results amongst primary school aged children from the USA and Brazil. A RCT [49] investigated the effects of a similar six month exercise session targeted intervention in 68 overweight children aged 5 to 10 years from a disadvantaged area in Brazil. After six months weight gain was less in the intervention group compared with controls (difference in change (IG-CG) $=-1.37 \mathrm{~kg} ; \mathrm{p}<0.001$ ) and there was significant decrease in BMI in the intervention group compared with controls (difference in change (IGCG) $=-0.53 \mathrm{~kg} \cdot \mathrm{m}^{2} ; \mathrm{p}=0.049$ ). A randomised controlled pilot study [50] investigated the effects of a twelve week culturally appropriate exercise session and screen time reduction targeted intervention amongst 61 low income African American girls aged 8 to 10 years in the USA. From baseline to post intervention, there were no significant differences between groups for changes in BMI and waist circumference (Additional file 2: Table S3); however, a trend towards better outcomes in the intervention group was noted.

Interventions in non-school settings which aimed to prevent obesity, or improve obesity-related behaviours (diet and/or physical activity) $(n=2)$ The final two community level studies evaluated group-based weight gain prevention educational targeted interventions in low SES children (one targeted parents only). These studies found that the interventions did not lead to beneficial effects after a relatively long follow-up (one year) in pre-school and primary school aged children. One was a non-randomised controlled study [51] of the effects of a mother and daughter twelve week culturally specific group based weight gain prevention educational intervention amongst 40 low SES, African American girls aged 7 to 12 years in USA (mean age $=10.0$ years). No intervention effects were observed for obesity outcomes after one year follow-up (Additional 2: Table S3). The other study was a RCT [52] of a health education intervention delivered to 1501 microcredit clients (families too poor to borrow from traditional lending institutions) in addition to their loans on their children aged less than five years in the Republic of Peru. The health education intervention was delivered by trained loan officers over eight months and covered basic child health provision, and discussion of clients own experiences and problem solving. There were no differences between the control and intervention groups in the change in the percentage of children who were overweight and in mean BMI z scores from baseline to one follow-up (Additional file 2: Table S3).

\section{Societal ( $n=1$ study)}

The 'best available' evidence for the environmental interventions comes from one strong quality experimental study that followed a universal approach and compared intervention effects of low SES children (using parent 
education as a proxy measure) versus higher SES children $[53,54]$. The study examined a multi-faceted school based obesity prevention intervention that was conducted in pre-schools in Switzerland. The intervention included changes to the school's environment to encourage physical activity (fixed and mobile equipment such as climbing walls, hammocks, balls and stilts) along with the provision of healthy snacks, nutrition education and exercise sessions. This reasonably sized study $(\mathrm{n}=625)$ found some beneficial intervention effects overall after $9 \frac{1}{2}$ months in terms of body fat and waist circumference, but not BMI or prevalence of overweight [54]. Sub-group analysis revealed no significant differences in intervention effects between children with low education parents and those with parents of medium/high education; however, there was a trend towards more beneficial effects in the higher SES children [53].

Mixed - individual, community and societal ( $n=1$ study) One strong quality experimental study [55] examined the effects of a three year community capacity-building intervention amongst 1,807 children of all SES aged 4-12 years in Australia (universal approach). The intervention was designed by a number of key organisations to build the community's capacity to create its own solutions to promoting healthy eating, physical activity and healthy weight, and the delivered universally in all intervention schools. After three years, children in the intervention schools showed significantly lower increases in waist circumference (adjusted difference between comparison and intervention $=-3.14 ; \mathrm{p}=0.01$ ) and BMI $\mathrm{z}$-score (adjusted difference $=-0.11 ; \mathrm{p}=0.04$ ) compared with the children in the control schools. There was no association between SES measures and intervention effects in the intervention schools; however, lower SES was associated with a greater gain in body fat and waist circumference in the control schools. Therefore, the intervention halted the widening of inequalities in obesity that would normally naturally occur over time.

\section{Discussion}

\section{What works in reducing inequalities in obesity-related} outcomes? for whom? and where?

At an individual level, the results from the 'best available' evidence $(\mathrm{n}=4)$ identified by our review suggests that mentor-based health promotion interventions may be effective in reducing obesity prevalence in low SES children as there were particular benefits to those low income children who were already overweight or obese (one year); and that a screen time reduction intervention was more beneficial for low SES children after two years.

The 'best available' evidence of the effectiveness of community level interventions $(n=17)$ was mixed, as whilst some studies identified effective interventions both in the short- and long-term (amongst children aged 6-12), others did not. Therefore, this review has found that there is some - but not conclusive evidence - that school based nutrition and physical activity education and exercise sessions and school-delivered screen time reduction interventions were effective in the longer term (over six months) in reducing obesity-related outcomes amongst school aged children with no differential effects by SES. In the shorter-term (up to six months), family based education and behavioural weight loss programmes, and exercise based weight loss programmes targeted at low SES school aged children were effective in reducing obesity-related outcomes. There was some evidence of effectiveness of school based nutrition and physical activity education and exercise sessions amongst pre-school children in the longer-term (one year). There was no evidence of effectiveness from the one 'best evidence' study amongst adolescents.

Our review identified only one strong quality experimental study of more upstream environmental interventions and no studies of the effects of macro-level policy interventions on obesity-related outcomes amongst children. The multi-faceted school based obesity prevention intervention was found to be effective amongst pre-school children in the longer term (over six months) but with slightly more beneficial effects to those of higher SES. Finally, a multi-level community capacity-building intervention was effective in preventing a widening of inequalities in obesity amongst children aged 4-12 over the long term (up to three years).

The majority of the 'best available' evidence was from interventions conducted in the USA or South America. In most cases interventions appeared to be equally effective - or ineffective - for boys and girls - although some studies did not distinguish their results by gender. Most of the studies were of interventions targeted at low SES children/areas and often of 'treatment' interventions for those already overweight or obese. In terms of 'where' interventions appeared to be effective, the 'best available' evidence was dominated by school-delivered interventions and this suggested that school-based interventions targeted at low SES children could have some beneficial effects in reducing inequalities - although the evidence was by no means conclusive. This is in line with the "Whole School Approach' to tackling childhood obesity. The findings of effectiveness are therefore very much limited to the effectiveness of school-based interventions, for low-income, primary school-aged children (6-12 years), particularly in the USA.

We did try to further unpick the various programme components that were used in the studies included in this review, to identify in detail why some interventions had a positive impact on inequalities in obesity-related outcomes, and others did not, particularly for interventions 
which appeared similar but had different effects. We did not systematically look for separate process evaluations as this was beyond the scope of the review, although we acknowledge that would have been helpful. From the information provided to us in the research papers, there were no consistent themes which shone through beyond those mentioned above. Importantly, there was no evidence that the studies included in this review increased inequalities in obesity-related outcomes. Whilst we wait for results of ongoing relevant interventions, and assuming interventions which tackle obesity-related outcomes do not increase inequalities, we suggest that interested stakeholders refer to a Cochrane review by Waters [30] which suggest the following to be promising policies and strategies:

- school curriculum that includes healthy eating, physical activity and body image

- increased sessions for physical activity and the development of fundamental movement skills throughout the school week

- improvements in nutritional quality of the food supply in schools

- environments and cultural practices that support children eating healthier foods and being active throughout each day

- support for teachers and other staff to implement health promotion strategies and activities (e.g. professional development, capacity building activities)

- parent support and home activities that encourage children to be more active, eat more nutritious foods and spend less time in screen based activities

\section{Implications for research}

The direction of research and evaluation in this field must move into how to implement effectively to scale, sustain the impacts over time, and ensure equitable outcomes of interventions to manage childhood obesity and reduce associated inequalities. We recommend larger, longer term studies, powered to detect the small changes that are likely to be found, with assessments of equity impacts, to enable translation of research findings into effective public health approaches for managing childhood obesity.

The majority of interventions that we included in this part of our review were aimed at preventing weight gain, although a number of 'treatment' interventions were also included. These 'treatment' interventions are more likely to show positive effects than prevention ones. The targeted approach also has limitations as even when interventions are effective amongst low income groups they are only able to reduce the health inequalities gap, they have little effect on the wider social gradient. Most studies were school based and aimed at primary school aged children (6-12 years). There were also very few studies of societal level interventions that might be expected to have more of an impact on the gradient in obesity [27]. We also found no studies that assessed the cost-effectiveness of interventions and meta-analysis was not appropriate given their heterogeneity.

Our results show that there is a clear need for more experimental studies of the effectiveness and costeffectiveness of interventions to reduce inequalities in childhood obesity, particularly in adolescents and in terms of macro-level interventions that potentially address the entire gradient. There has been a real missed opportunity to evaluate the effects of such 'real world' interventions, and future interventions (such as Fulfilling Lives: A Better Start) should include such analysis. It is worth highlighting the ongoing EPHE (EPODE for the Promotion of Health Equity) evaluation study which aims to provide useful information about the impact of the EPODE intervention on socioeconomic inequalities across Europe; 'Ensemble Prévenons l'Obésité Des Enfants' (EPODE, Together Let's Prevent Childhood Obesity) is a large-scale, coordinated, capacity-building approach for communities to implement effective and sustainable strategies to prevent childhood obesity [56].

\section{Implications for public health}

Our review has found only limited effectiveness of interventions with the potential to reduce SES inequalities in obesity. The body of evidence in this review provides some support for the hypothesis that obesity treatment interventions in children can be effective and that for interventions targeted at low SES children they have reduced obesity-related outcomes; for universal interventions they have reduced the SES gradient in obesity-related outcomes. Interventions need to be developed so that they can be embedded into ongoing practice and operating systems, rather than implementing interventions that are resource intensive and cannot be maintained long-term. This review also highlights that although we may now have a good sense of the range of interventions feasible for use in reducing the risk of childhood obesity, we lack the knowledge of which specific intervention components are most effective to ensure that the equity gradients reduced. Being able to answer this question is of critical importance to decision makers.

\section{Strengths and limitations}

This review was very extensive as an extremely thorough search was conducted of the international literature with a very broad inclusion and exclusion criteria that has ensured that the entire relevant evidence base was captured. This has enabled us to focus in this paper on just the best available (experimental) evidence. Quality is additionally high as double screening was applied and both data extraction and quality appraisal were independently 
checked. However, the review is still subject to some methodological limitations as for example the quality assessment tool, although described as a tool for public health interventions, seemed to favour those that followed a more clinical model. We particularly found the blinding question unhelpful as it mostly resulted in moderate scores. The definitions for level of intervention that were used, adapted from the health inequalities literature, meant that most studies were categorised as community level interventions. Other ways of categorising studies (such as by whether primary prevention programmes are more/less/even effective in decreasing or haltering inequalities compared to selective prevention programmes), or by examining the theoretical underpinning of interventions (such as those that are based on Social Cognitive Theory, Planned Behaviour or theories of Environment-Behaviour Relationships) could also have been used. One final limitation is our exclusion of studies that examined ethnic inequalities that may have reduced the USA literature where ethnicity is often used as a proxy for SES.

\section{Conclusion}

Our review has found only limited evidence of the effectiveness of interventions with the potential to reduce SES inequalities in obesity-related outcomes amongst children. These findings suggest that individual, community and societal-level interventions that aim to prevent obesity, treat obesity, or improve obesity-related behaviours (diet and/or physical activity) do not increase socioeconomic inequalities; many of the universal interventions have the potential to slow the widening of the obesity gap, and some of the interventions which are targeted at low SES children may be effective in decreasing obesity amongst lower socio-economic groups. Experimental studies of the effectiveness and cost-effectiveness of interventions to reduce inequalities in childhood obesity are needed, particularly in adolescents and in terms of macro-level interventions that potentially address the entire gradient, as well as evaluations of 'real world' interventions.

\section{Additional files}

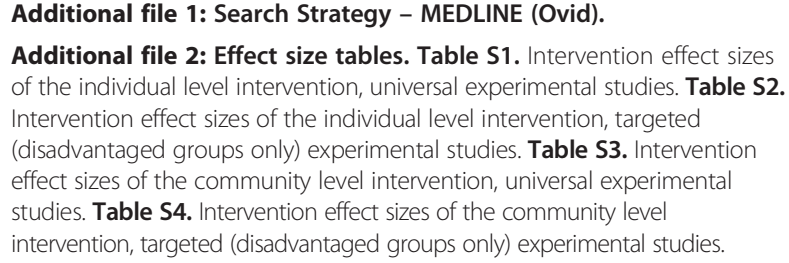

\section{Competing interests}

The authors declare that they have no competing interests.

\section{Authors' contributions}

FCH was responsible for data collection, and contributed to analysis, synthesis. She led the drafting of this article with support from CLB and CDS. CLB was the Principal Investigator and was responsible for overall design, co-ordination and project management. She provided methodological and conceptual direction, and contributed to analysis, synthesis and interpretation. JMC contributed to data collection and synthesis. AK contributed to analysis. HJM designed and conducted the searches and contributed to data collection. CDS provided methodological, analysis and synthesis input. All authors contributed to revised successive drafts of this article and approved the final version submitted for publication.

\section{Acknowledgements}

This article presents independent research funded by the National Institute for Health Research (NIHR) Public Health Research Programme (project number 09/3010/14). The views and opinions expressed are those of the authors and do not necessarily reflect those of the NHS, the NIHR, the Public Health Research programme or the Department of Health.

We would like to thank the members of our project steering group for their time and advice throughout the review: Goof Buijs (Netherlands Institute for Health Promotion and Disease Prevention), Richard Cookson (University of York), Liam Hughes (Local Government Improvement and Development), Mike Kelly (National Institute for Health and Clinical Excellence), Louise Potvin (University of Montreal) and Martin White (Newcastle University). We would also like to thank Jayne Kenworthy of the Wolfson Research Institute for Health and Wellbeing for her administrative support.

\section{Author details}

${ }^{1}$ Department of Geography, Wolfson Research Institute for Health and Wellbeing, Durham University Queen's Campus, Stockton-on-Tees TS17 6BH, UK. ${ }^{2}$ School of Medicine, Pharmacy and Health, Wolfson Research Institute for Health and Wellbeing, Durham University Queen's Campus,

Stockton-on-Tees TS17 6BH, UK. ${ }^{3}$ Wolfson Research Institute for Health and Wellbeing, Durham University Queen's Campus, Stockton-on-Tees TS17 6BH, UK.

Received: 3 February 2014 Accepted: 29 July 2014

Published: 11 August 2014

\section{References}

1. Lobstein T, Baur L, Uauy R: Obesity in children and young people: a crisis in public health. Obes Rev 2004, 5:4-85.

2. Wang $Y$, Lobstein T: Worldwide trends in childhood overweight and obesity. Int J Pediatr Obes 2006, 1:11-25.

3. Reilly JJ, Kelly J: Long-term impact of overweight and obesity in childhood and adolescence on morbidity and premature mortality in adulthood: systematic review. Int J Obes 2011, 35:891-898.

4. Rossen LM, Schoendorf KC: Measuring health disparities: trends in racial ethnic and socioeconomic disparities in obesity among 2- to 18-year old youth in the United States, 2001-2010. Ann Epidemiol 2012, 22:698-704.

5. El-Sayed A, Scarborough P, Galea S: Socioeconomic inequalities in childhood obesity in the United Kingdom: a systematic review of the literature. Obes Facts 2012, 5:671-692.

6. Howe LD, Tilling K, Galobardes B, Smith GD, Ness AR, Lawlor DA: Socioeconomic disparities in trajectories of adiposity across childhood. Int J Pediatr Obes 2011, 6:e144-e153.

7. Moschonis G, Tanagra S, Vandorou A, Kyriakou AE, Dede V, Siatitsa PE, Koumpitski A, Androutsos O, Grammatikaki E, Kantilafti M, Naoumi A, Farmaki AE, Siopi A, Papadopoulou EZ, Voutsadaki E, Chlouveraki F, Maragkopoulou K, Argyri E, Giannopoulou A, Manios Y: Social, economic and demographic correlates of overweight and obesity in primaryschool children: preliminary data from the Healthy Growth Study. Public Health Nutr 2010, 13:1693-1700.

8. Friel S, Chopra M, Satcher D: Unequal weight: equity oriented policy responses to the global obesity epidemic. BMJ 2007, 335:1241-1243.

9. OECD: Obesity and the Economics of Prevention: Fit not Fat. Paris: OECD Publishing; 2010. http://www.oecd.org/els/health-systems/obesityandtheec onomicsofpreventionfitnotfat.htm ISBN: 978-92-64-06367-9 (print); ISBN: 978-92-64084865 (PDF); Publication date: 23 September 2010. 
10. Shrewsbury $V$, Wardle J: Socioeconomic status and adiposity in childhood: a systematic review of cross-sectional studies 1990-2005. Obesity 2008, 16:275-284

11. Gordon D, Shaw M, Dorling D, Davey Smith G: Inequalities in Health: The Evidence Presented to the Independent Inquiry into Inequalities in Health, chaired by Sir Donald Acheson. Bristol: University of Bristol: Policy Press; 1999. http://www.policypress.co.uk/display.asp?K=9781861341747\&sf1= keyword\&st1=+ISBN+1+86134+174+1\&m=1\&dc=2 ISBN 1861341741

12. White M, Adams J, Heywood P: How and why do Interventions That Increase Health Overall Widen Inequalities Within Populations? In Health, Inequality and Public Health. Volume 65. Edited by Barbones S. Bristol: Policy Press; 2009.

13. European strategies for tackling social inequities in health: levelling up part 2. Available at: http://www.who.int/social_determinants/resources/ leveling_up_part2.pdf.

14. Graham H, Kelly M: Health Inequalities: Concepts, Frameworks and Policy. London: Health Development Agency; 2004

15. Whitehead M, Dahlgren G: Concepts and Principles for Tackling Social Inequities in Health: Levelling Up Part 1. Copenhagen: WHO Regional Office for Europe; 2006

16. Lorenc T, Petticrew M, Welch $V$, Tugwell P: What types of interventions generate inequalities? Evidence from systematic reviews. J Epidemiol Community Health 2013, 67:190-193.

17. Brown T, Platt $S$, Amos A: Equity impact of population-level interventions and policies to reduce smoking in adults: a systematic review. Drug Alcohol Depend 2014, 138:7-16.

18. Barr B, Bambra C, Whitehead M, Duncan WH: The impact of NHS resource allocation policy on health inequalities in England 2001-11: longitudinal ecological study. BMJ 2014, 348.

19. Magnée T, Burdorf A, Brug J, Kremers SP, Oenema A, van Assema P Ezendam NP, van Genugten L, Hendriksen IJ, Hopman-Rock M, Jansen W, de Jong J, Kocken PL, Kroeze W, Kwak L, Lechner L, de Nooijer J, van Poppel MN, Robroek SJ, Schreurs H, van Sluijs EM, Steenhuis IJ, van Stralen MM, Tak NI, te Velde SJ, Vermeer WM, Wammes B, van Wier MF, van Lenthe FJ, Jansen W, et al: Equity-specific effects of 26 Dutch obesity-related lifestyle interventions. Am J Prev Med 2013, 44:57-66.

20. Vander Ploeg KA, Maximova K, McGavock J, Davis W, Veugelers P: Do school-based physical activity interventions increase or reduce inequalities in health? Soc Sci Med 2014, 112:80-87.

21. Egan M, Bambra C, Petticrew M, Whitehead M: Reviewing evidence on complex social interventions: appraising implementation in systematic reviews of the health effects of organisational-level workplace interventions. J Epidemiol Commun Health 2009, 63:4-11.

22. Durand MA, Carpenter L, Dolan H, Bravo P, Mann M, Bunn F, Elwyn G: Do interventions designed to support shared decision-making reduce health inequalities? A systematic review and meta-analysis. PLoS One 2014, 9

23. Butland B, Jebb S, Kopelman P, McPherson K, Thomas S, Mardell J, Parry V: Tackling Obesities: Future Choices - Project Report. London: Government Office for Science; 2007.

24. Law C, Power C, Graham H, Merrick D: Obesity and health inequalities. Obes Rev 2007, 8:19-22.

25. Whitehead M: A typology of actions to tackle social inequalities in health. J Epidemiol Community Health 2007, 61:473-478.

26. Hillier-Brown F, Bambra C, Cairns-Nagi J-M, Kasim A, Moore H, Summerbell C: A systematic review of the effectiveness of individual, community and societal level interventions at reducing socioeconomic inequalities in obesity amongst adults. Int J Obes (Lond) 2014. Epub ahead of print.

27. Bambra C, Hillier F, Moore H, Summerbell C: Tackling inequalities in obesity: a protocol for a systematic review of the effectiveness of public health interventions at reducing socioeconomic inequalities in obesity amongst children. Syst Rev 2012, 1:16

28. PHR - Funded projects. http://www.phr.nihr.ac.uk/funded_projects/obesity.asp.

29. McLaren L, Mclntyre L, Kirkpatrick S: Rose's population strategy of prevention need not increase social inequalities in health. Int J Epidemiol 2010, 39:372-377.

30. Waters E, de Silva-Sanigorski A, Hall B, Brown T, Campbell K, Gao Y, Armstrong R, Prosser L, Summerbell C: Interventions for preventing obesity in children. Cochrane Database Syst Rev 2011, 12, CD001871

31. Effective public health practice project quality assessment tool for quantitative studies. http://www.ephpp.ca/tools.html.
32. Taveras EM, Gortmaker SL, Hohman KH, Horan CM, Kleinman KP, Mitchell K, Price S, Prosser LA, Rifas-Shiman SL, Gillman MW: Randomized controlled trial to improve primary care to prevent and manage childhood obesity: the High Five for Kids study. Arch Pediatr Adolesc Med 2011, 165:714-722

33. Wake M, Baur LA, Gerner B, Gibbons K, Gold L, Gunn J, Levickis P, McCallum Z, Naughton G, Sanci L, Ukoumunne OC: Outcomes and costs of primary care surveillance and intervention for overweight or obese children: the LEAP 2 randomised controlled trial. BMJ: Bri Med J 2009, 339.

34. Epstein LH, Roemmich JN, Robinson JL, Paluch RA, Winiewicz DD, Fuerch $\mathrm{JH}$, Robinson TN: A randomized trial of the effects of reducing television viewing and computer use on body mass index in young children. Arch Pediatr Adolesc Med 2008, 162:239-245.

35. Black MM, Hager ER, Le K, Anliker J, Arteaga SS, Diclemente C, Gittelsohn J, Magder L, Papas M, Snitker S, Treuth MS, Wang Y: Challenge! Health promotion/obesity prevention mentorship model among urban, black adolescents. Pediatrics 2010, 126:280-288.

36. Kain J, Uauy R, Albala, Vio F, Cerda R, Leyton B: School-based obesity prevention in Chilean primary school children: methodology and evaluation of a controlled study. Int J Obes Relat Metab Disord 2004, 28:483-493.

37. Jansen W, Borsboom G, Meima A, Zwanenburg EJV, MacKenbach JP, Raat H, Brug J: Effectiveness of a primary school-based intervention to reduce overweight. Int J Pediatr Obes 2011, 6:e70-e77.

38. Nemet D, Geva D, Eliakim A: Health promotion intervention in low socioeconomic kindergarten children. J Pediatr 2011, 158:796-801. e791.

39. Bingham M: Mediators and Moderators of the Effects of a children's Heart Health Intervention. Chapel Hill: University of North Carolina; 2002.

40. Simon C, Schweitzer B, Oujaa M, Wagner A, Arveiler D, Triby E, Copin N, Blanc S, Platat C: Successful overweight prevention in adolescents by increasing physical activity: a 4-year randomized controlled intervention [Erratum appears in Int J Obes (Lond). 2008 Oct;32(10):1606]. Int J Obes (Lond) 2008, 32:1489-1498.

41. Bellows LL: Development and Evaluation of Food Friends get movin' With Mighty Moves(tm), a Physical Activity Program to Prevent Obesity in low-Income Preschoolers. Colorado: ProQuest Information \& Learning; 2007.

42. de Meij JS, Chinapaw MJ, van Stralen MM, van der Wal MF, van Dieren L, van Mechelen W: Effectiveness of JUMP-in, a Dutch primary school-based community intervention aimed at the promotion of physical activity. $\mathrm{Br} J$ Sports Med 2011, 45:1052-1057.

43. Herrick $H$, Thompson $H$, Kinder J, Madsen KA: Use of SPARK to promote after-school physical activity. J School Health 2012, 82:457-461.

44. Lubans DR, Morgan PJ, Okely AD, Dewar D, Collins CE, Batterham M, Callister R, Plotnikoff RC: Preventing obesity among adolescent girls: one-year outcomes of the nutrition and enjoyable activity for teen girls (NEAT Girls) cluster randomized controlled trial. Arch Pediatr Adolesc Med 2012, 166:821-827

45. Sichieri R, Paula Trotte A, de Souza RA, Veiga GV: School randomised trial on prevention of excessive weight gain by discouraging students from drinking sodas. Public Health Nutr 2008, 12:197-202.

46. Walter HJ, Hofman A, Connelly PA, Barrett LT, Kost KL: Primary prevention of chronic disease in childhood: changes in risk factors after one year of intervention. Am J Epidemiol 1985, 122:772-781.

47. Robinson TN: Reducing children's television viewing to prevent obesity: a randomized controlled trial. JAMA 1999, 282:1561-1567.

48. Kalavainen MP, Korppi MO, Nuutinen OM: Clinical efficacy of group-based treatment for childhood obesity compared with routinely given individual counseling. Int J Obes (Lond) 2007, 31:1500-1508.

49. Alves JGB, Gale CR, Souza E, Batty GD: Effect of physical exercise on bodyweight in overweight children: a randomized controlled trial in a Brazilian slum. Original Title Efeito do exercicio fisico sobre peso corporal em criancas com excesso de peso: Ensaio clinico comunitario randomizado em uma favela no Brasil. Cad Saude Publica 2008, 24:S353-S359.

50. Robinson TN, Killen JD, Kraemer HC, Wilson DM, Matheson DM, Haskell WL, Pruitt LA, Powell TM, Owens AS, Thompson NS, Flint-Moore NM, Davis GJ, Emig KA, Brown RT, Rochon J, Green S, Varady A: Dance and reducing television viewing to prevent weight gain in African-American girls: the Stanford GEMS pilot study. Ethn Dis 2003, 13:S65-S77.

51. Willet SL: Health Risk Reduction Among African-American Females: A one Year Follow-up. ProQuest Information \& Learning; 1995.

52. Hamad R, Fernald LCH, Karlan DS: Health education for microcredit clients in Peru: a randomized controlled trial. BMC Public Health 2011, 11. 
53. Bürgi F, Niederer I, Schindler C, Bodenmann P, Marques-Vidal P, Kriemler S, Puder JJ: Effect of a lifestyle intervention on adiposity and fitness in socially disadvantaged subgroups of preschoolers: a cluster-randomized trial (Ballabeina). Prev Med 2012, 54:335-340.

54. Puder J, Marques-Vidal P, Schindler C, Zahner L, Niederer I, Bürgi F, Ebenegger V, Nydegger A, Kriemler S: Effect of multidimensional lifestyle intervention on fitness and adiposity in predominantly migrant preschool children (Ballabeina): cluster randomised controlled trial. BMJ: British Med J (Overseas \& Retired Doctors Edition) 2011, 343:945-945.

55. Sanigorski AM, Bell AC, Kremer PJ, Cuttler R, Swinburn BA: Reducing unhealthy weight gain in children through community capacity-building: results of a quasi-experimental intervention program, Be Active Eat Well. Int J Obes (Lond) 2008, 32:1060-1067.

56. Mantziki K, Vassilopoulos A, Radulian G, Borys J-M, du Plessis H, Gregório MJ, Graça P, de Henauw S, Handjiev S, Visscher TLS, Seidell JC: Promoting health equity in European children: design and methodology of the prospective EPHE (Epode for the Promotion of Health Equity) evaluation study. BMC Public Health 2014, 14.

doi:10.1186/1471-2458-14-834

Cite this article as: Hillier-Brown et al: A systematic review of the

effectiveness of individual, community and societal level interventions at reducing socioeconomic inequalities in obesity amongst children.

BMC Public Health 2014 14:834.

\section{Submit your next manuscript to BioMed Central and take full advantage of:}

- Convenient online submission

- Thorough peer review

- No space constraints or color figure charges

- Immediate publication on acceptance

- Inclusion in PubMed, CAS, Scopus and Google Scholar

- Research which is freely available for redistribution 